ISSN 2078-6441. Вісник Львівського університету. Серія географічна. 2014. Випуск 47. С. 88-97. Visnyk of the Lviv University. Series Geography. 2014. Issue 47. P. 88-97.

551.4:591.5

p.

\author{
олодимир ex $^{1}$, кс н ормило, емен укурудз ${ }^{2}$ \\ 1 ввівськ дослідн ст нція нституту рибного господ рств \\ вул. ввівськ, 11,81555, смт еликий юбінь, ввівськ обл., кр їн \\ 2 ввівський н ціон льний університет імені в н \\ вул. . орошенк , 41, 79000, м. ьвів, кр їн
}

прикл ді водозбірного б сейну р. ерещиця - чітко окресленої земноводної просторовофункціон льної геосистеми - про н лізов но рослинні (лісові й лучно-болотні), тв ринні (мисливські й рибні) ресурси, т кож роль фіто- і зоопл нктону в поліпшенні кормової б зи рибного господ рств . 'ясов но вз ємозв'язки і вз ємоз лежності біотичних і біотичних компонентів природного довкілля т вплив н них нтропічних чинників.

лючові слов : біотичні ресурси, водозбірний б сейн, б сейновий підхід, р ціон льне використ ння, відтворення, охорон біоти.

всі ч си існув ння людини їі життя н йбільше 3 леж ло від біотичних ресурсів, якими вон х рчується, виготовляє одяг, з яких будує помешк ння. ост нне століття для своїх потреб людство щор з більше використовує продукцію хімічного синтезу, що певною мірою посл било $з$ лежність людини від цих ресурсів. одноч с потреб в біотичних ресурс х не зменшил ся, н вП ки - зросл, н с мперед з огляду н збільшення н родон селення пл нети (у 2011 р., з д ними , воно досягло 7 млрд осіб). ля цієї кількості людей щороку потрібно орієнтовно 7 млн т продуктів х рчув ння. якщо до цього дод ти потреби льтерн тивної енергетики (біоп ливо), рекре ції тощо, то ст не зрозумілим, чому біотичні ресурси м ють і нині бсолютний соці льно-економічний пріоритет у з безпеченні життєдіяльності людської спільноти.

іогеогр фічні дослідження д ли змогу оцінити кількість видів флори і ф уни, грибів і мікроорг нізмів, орієнтовно підр хув ти обсяги т співвідношення біотичних ресурсів н уходолі т в вітовому оке ні, т кож визн чити продуктивність кожного біому - від вічнозелених екв торі льних дощових лісів до полярних пустель.

к демік - родзинський (2002) ув ж в, що н території кр їни поширено пон д 3,5 тис. рослинних соці цій. іот кр їни н лічує 70,7 тис. видів живих орг нізмів, 3 яких близько 26 тис. (25 888) видів н лежить до флори, у тім числі м йже 15 тис. видів грибів, які утворюють окреме ц рство, проте 3 тр дицією н леж ть до флори, і 45 тис. видів (44 800) - до ф уни, у скл ді якої перев ж ють безхребетні (пон д 26 тис. видів). ун хребетних предст влен кл с ми сс вців (100), пт хів (360), пл зунів (20), земноводних (17) і риб (200). росторове поєдн ння цих орг нізмів формує велику кількість екосистем, утворюючи дуже строк тий орн мент. веден “ст тистик" є своєрідним тлом, н якому формуються регіон льні й лок льні поєдн ння біотичних ресурсів. дним з т ких територі льних утворень є водозбірний б сейн p. ерещиця - лівої притоки верхнього річищ ністр . ічковий б сейн $є$ доволі

(C) рех ., ормило ., укурудз ., 2014 
зручним полігоном не тільки для кількісного, й для комплексного дослідження біотичних ресурсів.

ст ннім ч сом чим ло дослідників з стосовують 6 сейновий підхід у різних природничо-геогр фічних дослідженнях, зокрем . ов льчук (1997), . щенко (1999), . ух (2000), . илипович (2004), . вловськ (2006), . рус к (2009), . одня (2014) т ін. іотичні ресурси б сейну ерещиці, їхнє господ рське, рекре ційне, природоохоронне зн чення відобр жено в пр цях . ндрейко (2002), . енсірук (1995), . у узія (1997), . pex $(2007,2009)$. нязя (2007) т ін. им ло корисної інформ ції з фіксов но у фондових м тері л х ост нніх років: лісо- т рибогоспод рських, природоохоронних структур, ст тистичних орг нів, мисливських тов риств [16-21] н ліз опубліков них і фондових м тері лів д є змогу уз г льнити б чення ст ну господ рського використ ння й охорони біотичних ресурсів одного з водозбірних $б$ сейнів річки, що розміщений у безпосередній близькості від великого міст .

біотичне життеве середовище. тектонічному пл ні водозбірний б сейн ерещиці розт шов ний у меж х ьвівського п леозойського прогину, у зоні зчленув ння хідноєвропейської пл тформи 3 ередк рп тським кр йовим прогином. геоморфологічного погляду $б$ сейн приурочений до трьох геоморфологічних р йонів: горбогірного п см озточчя, ом рнівської горбкув тої рівнини (рис. 1) т ерхньодністерської люві льної рівнини. півночі він обмежений лінією оловного вропейського вододілу. сейн почин ється у природному $\mathrm{p}$ йоні озточчя (височинний тип л ндш фтів), з якого у верхній течії річище ерещиці прямує в південно-східному н прямі, потім круто (м йже н $150^{\circ}$ ) поверт $є$ н південний 3 хід, 3 широти ьвов тече в південному н прямі, вп д ючи в ністер. середній течії б сейну поширений рівнинний (опільський) тип л ндш фтів. південь від широти м. ом рно рівнинні л ндш фти н був ють вир зних рис низовинного типу, х р ктерного для цієї ч стини долини ністр .

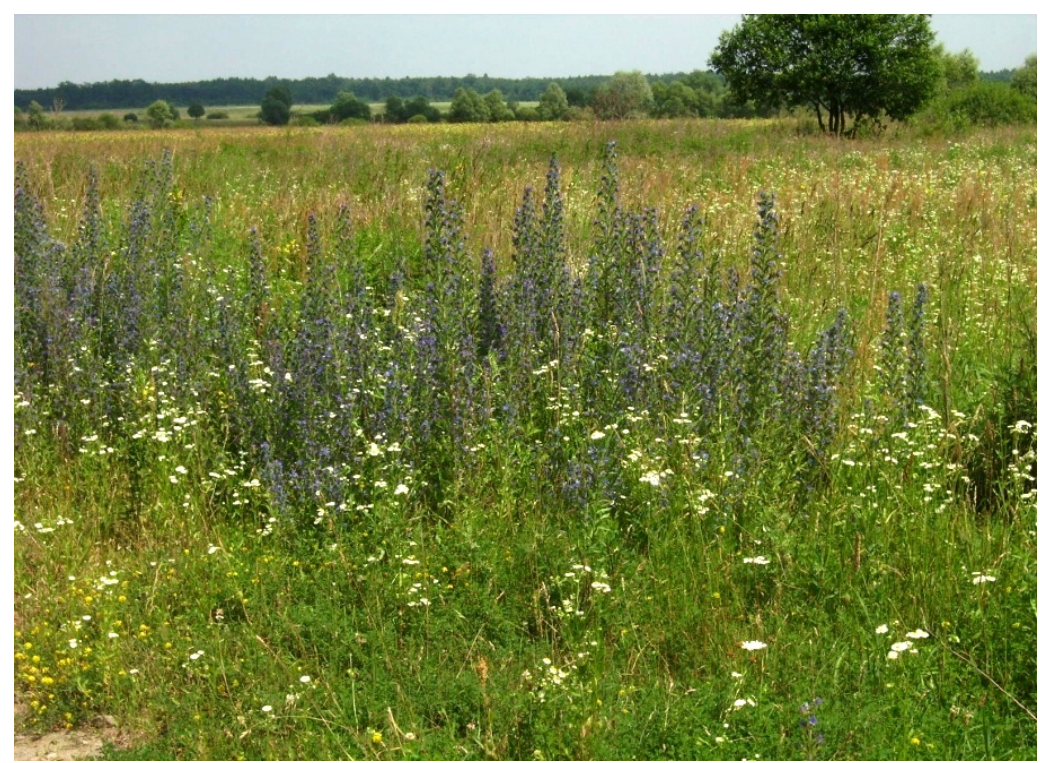

ис. 1. ом рнівськ горбкув т рівнин поблизу гирл ерещиці (фото . нязя) 
геобот нічному р йонув нні кр їни (1977) північн ч стин досліджув ної території н лежить до емирівсько- герівського р йону озтоцького округу ентр льноєвропейської провінції, південн - до ирецького р йону ременецькоотинського округу хідноєвропейської провінції.

овжин p. ерещиці ст новить 92 км. лощ водозбору $-955 \mathrm{kм}^{2}$. итік почин ється 3 джерел північно-з хідних схилів озточчя, н пересічній висоті 300-340 м, вп д є в ністер - н висоті 260 м. олин перев жно тр пецієподібн, у деяких місцях верхньої течії - V-подібн , шириною 2-4 км. пл в широк - 1,0-1,5 км з озероподібними розширеннями до 2-3 км і більше (рис. 2) [13].

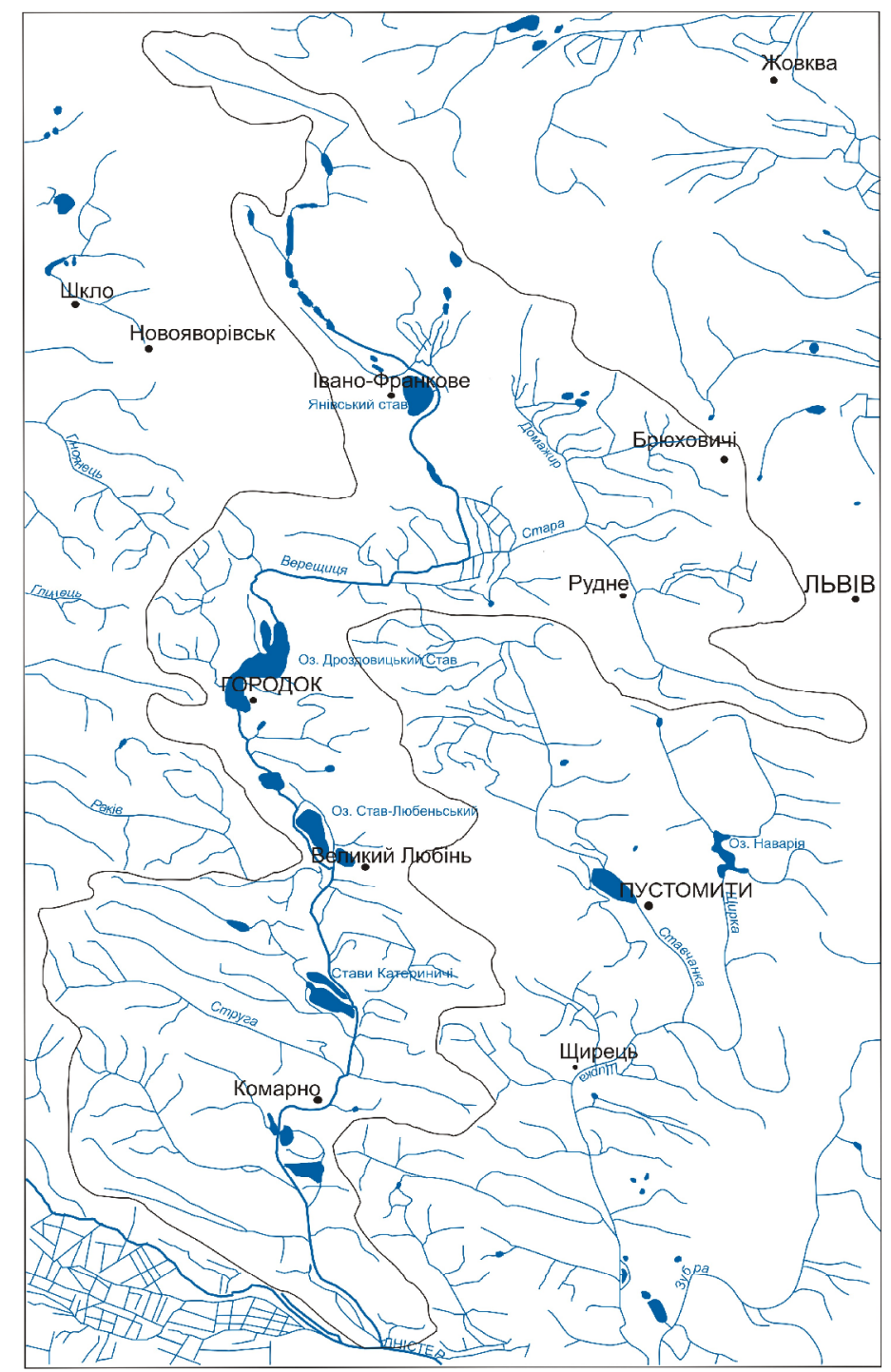

ис. 2. ідрогр фічн мереж 6 сейну ерещиці [10] 
ідрогр фічну мережу ерещиці формують вісім річок довжиною пон д 10 км. овжин цих річок - 199 км, їхніх допливів довжиною до 10 км н р ховують 246, що в сумі ст новить 318 км. г льн кількість річок у б сейні - 254, їхня довжин 517 км (т бл. 1) [10].

блиця 1

йбільші притоки ерещиці

\begin{tabular}{|c|c|c|c|}
\hline ік & $\begin{array}{c}\text { р в чи лів } \\
\text { приток }\end{array}$ & $\begin{array}{c}\text { овжин }, \\
\text { км }\end{array}$ & $\begin{array}{c}\text { лощ } \\
\text { сейну, км }\end{array}$ \\
\hline т р рік & & 24 & 224 \\
\hline шковиця & & 14 & 17 \\
\hline ерестин & & 16 & 37 \\
\hline олонк & & 7 & 29,6 \\
\hline Струг & & 15 & 41 \\
\hline
\end{tabular}

олини допливів ерещиці у верхів'ях - вузькі (0,5-1,0 км) і глибоко вріз ні (30-55 м), у середній і нижній течії - розширені, шириною до 2 км. пл в у верхній течії сл бко вир жен , нижче 3 течією двостороння, шириною 0,2-1,0, місцями - 2,0-2,5 км. хня поверхня хвиляст , місцями з болочен . ічищ помірно звивисті, подекуди к н лізов ні. ередня швидкість течій колив ється 0,2-0,7 м/с. ічище ерещиці утворюється від злиття двох безіменних потоків н бсолютній висоті н д рівнем моря 345 м, гирло є н висоті 260 м н. р. м.

ервинний вигляд л ндш фтів б сейну ерещиці сформув вся вн слідок т нення льодовик ніпровського зледеніння, південн меж якого проходил субмеридіон льно, тобто вздовж озточ нської височини. дним з т ких післяльодовикових колекторів було річище ерещиці, яким т лі води стік ли н південь у б сейн ністр . ісля відступу льодовик у річищі ерещиці утворились озер, які ст ли кумулятор ми пелітової, левритової т піщ ної фр кцій донних відкл дів.

біотичні компоненти (чинники) - четвертинні відкл ди, рельєф, клім т, води “диктув ли” формув ння угрупов нь місцевої біоти, які с мі постійно змінюв лися і вплив ли н зміну біоти. ост нні декільк століть н тлі поступового природного дикт ту поч в діяти дикт т нтропогенний. іяльність людини н території б сейну змінил пр д вні л ндш фти т їхні компоненти, чим суттєво коригув л природну екологічну ситу цію, з звич й, у гірший бік. меж х б сейну нтропогенний вплив н л ндш фтні системи відбув вся вн слідок дії т ких чинників [11]:

$\rightarrow$ сільськогоспод рського використ ння (рільництво, тв ринництво);

$\rightarrow$ лісогоспод рського використ ння (вирубув ння лісів, трелюв ння деревини, вип с ння худоби);

$\rightarrow$ з будовне т комунік ційне використ ння (будівництво поселень, шляхів сполучення, трубопроводів і високовольтних ліній електроперед ч);

$\rightarrow$ спорудження гідротехнічних об'єктів (меліор тивні системи, греблі, к н ли, ст ви);

$\rightarrow$ гірничодобувне т промислово-технічне використ ння (видобуток і переробк корисних коп лин, будівництво т експлу т ція промислових підприємств);

$\rightarrow$ культурно-технічне використ ння (розчищення території від дерев, ч г рників, пеньків, лісовідновлюв льні роботи);

$\rightarrow$ рекре ційн діяльність (дигресія рослинного покриву, експлу т ція рекре ційних споруд тощо). 
ожний вид т кого впливу м в перев жно нег тивні н слідки щодо умов природного функціонув ння л ндш фтних систем.

іотичні ресурси. сейнов систем охоплює зн чну кількість геосистемних скл дових: компонентів, елементів і чинників, які в процесі мет болізму постійно змінюються i змінюють природне довкілля, формуючи біотичне і л ндш фтне різном ніття. н ліз біотичних ресурсів у меж х річкового б сейну розглянемо в т кій послідовності:

$\rightarrow$ рослинні ресурси (ліси, луки й болот );

$\rightarrow$ тв ринні ресурси (мисливськ ф ун , рибні ресурси).

icu. лощ вкритого лісовою рослинністю б сейну ерещиці ст новить 14 тис. г, бо 14,7\% від з г льної площі б сейну. лісненість б сейну нерівномірн - вон зменшується з півночі н південь, від $65 \%$ н озточчі до 6-7\% у гирлі б сейну [16]. озтоцькій ч стині б сейну п нівними є букові, дубово-соснові т дубово-гр бові ліси. ут перев ж ють соці ції букових лісів - волосистоосокового (Fagetum caricosum), м ренкового ( $F$. asperulosum) т кв сеницевого ( $F$. oxsalidosum) флористичного скл ду. середній і південній ч стин х 6 сейну перев ж ють дубові ліси, що пояснюють рівнинним рельєфом і оглеєними грунт ми, н яких конкуренти дуб - бук і гр б - гірше прижив ються. убові ліси предст влені соці ціями Guergetum (трясучковидноосокового, м ренкового т кв сеницевого скл ду). іпше дренов ні ділянки 3 йняті дубово-гр бовими, вершини вододілів - буковими ліс ми $[3,16]$.

хвойні деревні породи прип д є 5229 г (37,3\%), твердолистяні - 7179 (51,2), м'яколистяні - 1606 г (11,5\%) [16]. г льний 3 п с деревини ст новить м йже 1,2 млн м ${ }^{3}$. ні щодо основних типів лісу в меж х 6 сейну ерещиці свідч ть про те, що в цьому р йоні є великі можливості підвищення продуктивності лісів. оловн 3 них - відновлення корінних типів деревост нів і введення швидкорослих екзотів, т ких як модрин (Larix), псевдотсуг (Pseudotsuga). перезволожених ділянк х н йбільший приріст д є тополя біл (Populus alba) і чорн, яку ще н зив ють осокip (P. nigra). Д ними . енсірук [2, с. 188] “ оптим льних умов х місцезрост ння деревост ни тополі у віці 20-25 років м ють з п с 500-600 м $3 / \Gamma$ (сосн т кого з п су досяг є у віці 100 років, смерек - 80, дуб і бук - у віці 150)”.

уки й болот . природному покриві регіону зн чну площу з йм є лучн рослинність. уки й болот н території б сейну річки ерещиці з йм ють $18 \%$. озтоцькій ч стині це перев жно суходільні й 3 пл вні луки. уходільні луки предст влені форм ціями костриці (Festuceta rubra, F. pratensis). еред з пл вних луків перев ж ють болотисті т торфовисті. середній і південній ч стин х 6 сейну луки сформув лися головно н місці осушених боліт, рідше - н місці вируб них лісів. олотисті луки перев жно приурочені до річкових з пл в, подекуди тут тр пляються й спр вжні луки. н чн ч стин колишніх луків розор н, тому простежується фр гмент рний розподіл як болотистих, т к і суходільних відмін, кожн з яких м є своєрідний видовий скл д і структуру. омінують тр в'янисті т тр в'янисто-мохові болот : очеретяні, рогозові, хвощеві, осоково-гіпнові. ідше тр пляються вільхові болот . соці тивний скл д спр вжніх лук перев жно лисохвостовий (Alopecureta pratensis) т лучнокострицевий (Festuceta pratensis) [3].

родуктивність лук, як і якість сін , оцінюють у широкому ді п зоні: від кількох до десятків центнерів 31 г, якість - від м лоприд тного до високоякісного. кщо 3 пересічний пок зник прийняти 5 ц/г, то з г льн біом с сухої речовини (сін ), яку можн отримув ти щороку в меж х 6 сейну ерещиці, ст новитиме орієнтовно 85950 ц. 
в ринний світ. кількістю видів серед хребетних н досліджув ній території домінують пт хи. г лом н ьвівщині є 340 видів хребетних тв рин, з яких 199 видів пт хів. холодний період року більшість з них відліт є у вирій. одноч с $є$ пт хи, які приліт ють у н ш кр й н зимівлю: снігур (Pyrrhula pyrrhula L.), дрізд-омелюх (Turdus viscivoris), зимняк (Buteo lagopus), чечітк (Acanthis flammea L.), пуночк (Plectrophanes nivalis) [8]. місцем поширення і гніздув ння пт хів можн умовно розділити н кільк груп: водопл вні, полів і лук, лісові т з будов них культурних л ндш фтів. еякі пт хи гніздяться т кож у суміжних фітоценоз х і л ндш фт х. перн тої дичини перев ж ють к чки, лиски, сірі куріпки, кулики, перепілки. р пляються т кож орябок (рябчик), тетерук. сі вони в мисливський сезон ст ють цінною здобиччю мисливців.

території $б$ сейну ерещиці є близько 56 видів сс вців, предст влених шістьм ряд ми: ком хоїдні, рукокрилі, хижі, п рнокопитні, з йцеподібні і гризуни. ризуни вирізняються н йвищою видовою різном нітністю т чисельністю. ільшість рукокрилих н лежить до рідкісних. д ними мисливських господ рств, у меж х $б$ сейну поширено 15 видів звірів. -поміж хутрових звірів н йбільше поширені з єць-рус к, онд тр , куниця, тхір чорний, борсук, білк , лисиця т інші, т кож копитні - олені, козулі, к $б$ ни. ількість копитних у лісових угіддях $б$ сейну поступово зрост $є$. е пояснюють тим, що полюв ння н оленя звич йного (Cervus elaphus), к 6 н дикого (Sus scrofa) і козулю (Capreolus capreolus) тепер дозволене лише з спеці льними ліцензіями [17-20].

ідробіологічні дослідження ерещиці т ст вів рибодільниці “ еликий юбінь” м ють в жливе зн чення тому, що в основі трофічної пір міди водного біоценозу є фітопл нктон, яким живиться зоопл нктон (т бл. 2).

блиця 2

озвиток фітопл нктону ерещиці

\begin{tabular}{|c|c|c|c|c|c|c|c|c|c|c|}
\hline \multirow{2}{*}{$\begin{array}{c}\text { рупи водорос- } \\
\text { тей } \\
\end{array}$} & \multicolumn{2}{|c|}{ т ція 1} & \multicolumn{2}{|c|}{ т ція 4} & \multicolumn{2}{|c|}{ т ція 5} & \multicolumn{2}{|c|}{ т ція 9} & \multicolumn{2}{|c|}{ т ція 10} \\
\hline & тис. кл/ $/ \mathrm{M}^{3}$ & $\Gamma / M^{3}$ & Тис. кл/ $/ \mathrm{M}^{3}$ & $\Gamma / M^{3}$ & тис. кл/ $/ \mathrm{M}^{3}$ & $\Gamma / M^{3}$ & тис. кл/ $/ \mathbf{M}^{3}$ & $\Gamma / \mathbf{M}^{3}$ & тис. кл/ $/ \mathbf{M}^{3}$ & $\Gamma / M^{3}$ \\
\hline $\begin{array}{r}\text { иньо-зелені } \\
\text { (Cуапорhyta) }\end{array}$ & 1000 & 0,02 & 1000 & 0,05 & 2030 & 0,06 & 200 & 0,01 & 200 & 0,01 \\
\hline $\begin{array}{c}\text { вгленові } \\
\text { (Euqlenophyt ) }\end{array}$ & 60 & 0,18 & 130 & 0,27 & 200 & 0,42 & 100 & 0,11 & 100 & 0,07 \\
\hline $\begin{array}{r}\text { инофітові } \\
\text { (Dinophyta) }\end{array}$ & 10 & 0,06 & - & - & 20 & 0,11 & - & - & - & - \\
\hline $\begin{array}{c}\text { і томові } \\
\text { (Bacillariophyta) }\end{array}$ & 330 & 0,36 & 990 & 1,62 & 1110 & 1,74 & 400 & 0,76 & 400 & 0,11 \\
\hline $\begin{array}{c}\text { елені } \\
\text { (Chlorophyta) }\end{array}$ & 260 & 0,07 & 1870 & 0,48 & 7660 & 0,84 & 5600 & 0,58 & 1930 & 0,36 \\
\hline сього & 1660 & 0,69 & 3990 & 2,42 & 11020 & 3,17 & 6300 & 1,46 & 2350 & 0,55 \\
\hline
\end{tabular}

кісний скл д фітопл нктону дослідних ст вів був доволі низьким (0,1, 0,3, 1,1 мг/л). ерев ж ли зелені водорості. о форм, які вплив ли н біом су фітопл нктону, н леж ть протококові водорості родів Scenedesmus, Pediastrum т oleastrum. piм того, у серпні-вересні м сово розвив лись синьо-зелені водорості (Aphanizomenon fiosaguae, Microcystis aeruginoza), які спричиняли “цвітіння води” (див. т бл. 3). 
ередньосезонн біом с фітопл нктону дослідних ст вів рибодільниці “ еликий юбінь”, мг/л

\begin{tabular}{|c|c|c|c|c|c|c|}
\hline \multirow{2}{*}{ рупи водоростей } & \multicolumn{6}{|c|}{ т в } \\
\cline { 2 - 7 } & \multicolumn{2}{|c|}{ № 24(2) } & \multicolumn{2}{c|}{ № 24(3) } & \multicolumn{2}{c|}{ № 24(4) } \\
\cline { 2 - 7 } & мг/л & \% & мг/л & \% & мг/л & \% \\
\hline иньо-зелені & 1,6 & 22,5 & 1,5 & 21,8 & 1,4 & 22,2 \\
\hline вгленові & 0,1 & 1,4 & 0,1 & 1,4 & 0,3 & 4,8 \\
\hline елені & 4,3 & 60,6 & 4,2 & 60,9 & 4,3 & 54,0 \\
\hline і томові & 1,1 & 15,5 & 1,1 & 15,9 & 1,1 & 19,0 \\
\hline сього & $\mathbf{7 , 1}$ & $\mathbf{1 0 0}$ & $\mathbf{6 , 9}$ & $\mathbf{1 0 0}$ & $\mathbf{6 , 3}$ & $\mathbf{1 0 0}$ \\
\hline
\end{tabular}

ередня з сезон біом с фітопл нктону в ст ві № 24 (2) ст новил 7,1 мг/л, у ст ві № 24 (3) - 6,9, у ст ві № 24 (4) - 6,3 мг/л.

сезонному розвиткові зоопл нктону дослідних ст вів простежен подібн дин міК . ксим льний приріст біом си з фіксов но н прикінці тр вня-н поч тку черв-

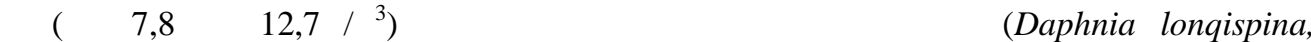
Bosmina lonqirostris). рім того, у зоопл нктоні ст вів зн чне місце з йм ли веслоногі р коподібні (Cyclops strenuonus) т коловертки (Asplanohnasp., Bachionus calioflorus). ередньосезонн біом с зоопл нктону ст вів № 24 (2) ст новил 5,3 г/м³ ; № 24 (3) 5,2 ; № 24 (4) $-5,0$ г/ $\mathrm{M}^{3}$ (т бл. 4).

блиця 4

ередньосезонн біом с зооопл нктону дослідних ст вів рибодільниці “ еликий юбінь”, г/м³

\begin{tabular}{|c|c|c|c|c|c|c|}
\hline \multirow{2}{*}{ рупи орг нізмів } & \multicolumn{9}{|c|}{ т в } \\
\cline { 2 - 7 } & \multicolumn{2}{|c|}{ № 24 (2) } & \multicolumn{2}{|c|}{ № 24 (3) } & \multicolumn{2}{c|}{ № 24 (4) } \\
\cline { 2 - 7 } & бiом c & $\mathbf{\%}$ & бiом c & \% & бiом c & \% \\
\hline оловертки & 1,2 & 22,6 & 1,1 & 21,2 & 0,9 & 18 \\
\hline іллястовусі р коподібні & 3,4 & 64,2 & 3,3 & 63,4 & 3,1 & 62 \\
\hline еслоногі р коподібні & 0,7 & 13,2 & 0,8 & 15,4 & 1,0 & 20 \\
\hline сього & $\mathbf{5 , 3}$ & $\mathbf{1 0 0}$ & $\mathbf{5 , 2}$ & $\mathbf{1 0 0}$ & $\mathbf{5}$ & $\mathbf{1 0 0}$ \\
\hline
\end{tabular}

ч с дослідження річки, іï гідробіотичних ресурсів т ресурсів прибережних урочищ відбулися зн чні зміни. идовий скл д риб збільшився, епізоотичний ст н поліпшився, вод ст л чистішою і прозорішою, без н явності у ній н фтопродуктів.

ілководдя річки покрилося т кими м кроліт ми, як рогіз, очерет, осок , лепех , черед трироздільн .

ст нніми рок ми ерещиця повернул собі сл ву рибної річки. оліпшився кількісний і якісний скл д гідробіотичних ресурсів. ьогодні тр пляються коропи і щуки м сою пон д $5 \mathrm{Kг,} \mathrm{к} \mathrm{р} \mathrm{сі} \mathrm{-} \mathrm{близько} 1$ кг. рибережн рослинність 3 з 6 рвленням і біом сою м є ліпший екост н.

ибні господ рств були і є спонт нним джерелом з безпечення рибним пос дковим м тері лом усього б сейну ерещиці, оскільки під ч с спусків ст вкових вод р зом 3 водою у річки потр пляє ч стин ст вкової риби: короп (Cyprinus carpio), білий мур (Ctenopharyngodon idella), товстолобики білий (Hypophthalmichthys molitrix) т 
строк тий (Aristichthys nobilis). рім цих видів, у річці водяться к р сь (Carassius), щук (Esox lucius), окунь (Perca), сом (Silurus glanis) т ін. [7, 21].

н слідок гідромеліор тивних робіт (поглиблення русл в $\mathrm{p}$ йоні сіл ерляни i еликий юбінь) зменшилося з рост ння річки синьо-зеленими водоростями і поліпшилися умови для розвитку водної ф уни. овстолобик, білий мур т інші види, спожив ючи м крофіти, позитивно вплив ють н кв фітоценоз і т к регулюють водну екосистему з г лом. ому будь-яке господ рське втруч ння в с морегулюв льну

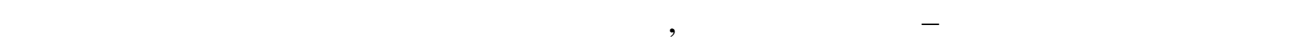
уникнення шкідливих і непередб чув них явищ. осліджуючи біотичні ресурси, в рто ретельно вр ховув ти передумови їхнього виникнення, розвитку, поширення, використ ння й охорони. ередня ч стин ерещиці т іï б сейн м є скл дну систему вз ємозв'язків: суходільних і водних, біотичних і біотичних компонентів, відт к і ресурсів, які 3 продум ного втруч ння людини г рмонійно функціонують і не погіршують природно-ресурсного потенці лу.

p зі з стосув ння 6 сейнового підходу м ємо змогу з пропонув ти природоохоронні $з$ ходи для кожного 3 трьох типів л ндш фтів: озтоцького, ородоцькоирецького т ом рнівського [11, 12, 14].

ля підвищення екологічної стійкості б сейнової системи ерещиці рекомендуємо вжив ти низку природоохоронних з ходів:

$\rightarrow$ поступово зменшув ти площу розорюв них земель (для опільських л ндш фтів);

$\rightarrow$ біля річищ річок, з лежно від к тегорії, виділяти водоз хисні смуги шириною 25-50 м і з с джув ти їх лісовою (ч г рниковою, тр в'яною) рослинністю (для всіх типів л ндш фтів);

$\rightarrow$ з безпечув ти з хист від з топлення повеневими і п водковими вод ми поселень (для низовинних л ндш фтів);

$\rightarrow$ створюв ти нові й розширюв ти н явні природоохоронні об’єкти (для всіх типів л ндш фтних систем);

$\rightarrow$ зменшув ти обсяги вирубув ння лісів і відновлюв ти їхні н с дження в місцях суцільного вирубув ння (розтоцькі л ндш фти);

$\rightarrow$ н лежно очищув ти стічні води перед скид нням їх у природні водойми (усюди). метою поліпшення вирощув ння у ст вк х екологічно чистої і високоякісної рибної продукції пропонуємо уник ти:

$\rightarrow$ неефективного використ ння водних площ, прид тних для вирощув ння тов рної риби (поки що лише 10 \% т ких площ використовують ефективно);

$\rightarrow$ м лопродуктивного т м ло сортиментного вирощув ння кв культур;

$\rightarrow$ техногенного впливу н екологічний ст н водойм, одн к дотримув тися вимог до якості вод з рибнених водойм.

истемно-узгоджене дотрим ння н ведених з ходів д є змогу поступово оптимізув ти використ ння і відтворення біотичних ресурсів не тільки в б сейні ерещиці, й в суміжних річкових 6 сейн х і т к сприяти ст лому г рмонійному розвиткові 3 хідного регіону кр їни.

тже, обгрунтов но спробу розгляд ти водозбірний б сейн як природногоспод рську систему вз ємодії людини з природним довкіллям, у меж х якої можн доволі точно прогнозув ти обсяги біотичних ресурсів т м ти позитивні н слідки господ рюв ння з умови з стосув ння продум них господ рських т природоохоронних 3 ходів. голошено н тому, що в меж х річкового б сейну є зн чн територі льн диференці ція л ндш фтних систем т біотичних ресурсів. ому в господ рській 
діяльності людини треб вр ховув ти особливості кожного виду (типу) т ких територільних систем. пропонов но низку природоохоронних 3 ходів як для всього водозбірного б сейну, т к і для його окремих ч стин - височинної, рівнинної і низовинної.

пеці льні рекоменд ції з пропонов но для вирощув ння у ст вк $\mathrm{x}$ екологічно чистої і високоякісної рибної продукції з ур хув нням екологічного ст ну вод водних об'єктів, продуктивності фіто- і зоопл нктону з умови перм нентного моніторингу природного довкілля.

1. ндрейко . . рирод ородоччини / . . ндрейко. - ьвів : - л сик 2002. $-52 \mathrm{c}$.

2. енсірук . . іси кр їни / . . енсірук. - . : у ук. думк , 1992. -408 с.

3. еобот нічне р йонув ння кр їнської _. - . : ук. думк , 1977. - 304 с.

4. еренчук.. еоморфологічні спостереження н ністровсько- янському межиріччі / . . еренчук // еогр. зб. - . : ид-во , 1956. - ип. 1. .201-206.

5. родзинський . . іогеогр фічні спекти рослинного і тв ринного світу кр їни / . . родзинський // иїв. геогр. щорічник. - 2002. - ип. 1. - . 7-31.

6. pex . ункціон льн роль зооценозу середньої ч стини б сейну р. ерещиці, його вз ємозв'яз ність з біорізном нітністю / . рех // иор знообр зие и роль животных в екосистем х : тери лы V ежд. н уч. конф. (г. непропетровск, 12 октября 2007 г.). - непропетровск, 2007. - . 1-3.

7. pex. ибні ресурси б сейну річки ерещиці: використ ння, відтворення й охорон / . pex// існик ьвів. ун-ту. ер. геогр. - 2009. - ип. 37. - . 164-176.

8. узій . . ун і н селення хребетних з хідного регіону кр їни. . 1. озточчя / . . узій. - ., 1997. - 161 с.

9. ітовський . одні пт хи озточчя / . ітовський, . рогулець, . іонцек // існик ьвів. ун-ту. ер. біол. - 1991. - ип. 21. - .63-68.

10. нязь . . біотичні компоненти л ндш фтів б сейну річки ерещиця // тері ли VIII сеукр. студ. н ук. конф. - ьвів, 2007. - . 15-28.

11. ов льчук . . егіон льний еколого-геоморфологічний н ліз / . . ов льчук. ьвів : нститут укр їнозн вств , 1997. - 440 с.

12. укурудз . . ідроекологічні проблеми суходолу : н вч. посібник / ред. проф. . ільчевського / . . укурудз .- ьвів : віт, 1999. - 232 с.

13. $н$ н кнов . . ерещиця / . . н ц к нов , . . тойко // , т. 1. - . “ кр. енциклопедія” ім. . . ж н , 1993. - . 160.

14. $y x$. ндш фтн к рт ьвівської обл сті м сшт бу 1:200 000 // існик ьвів. ун-ту. ер. геогр. $-2003 .-$ ип. 29, ч. $1 .-$ - .58-65+к рт с. 260.

15. рирод ьвівської обл сті / [ ред. проф. . . еренчук ]. - ьвів : ид-во ьвів. ун-ту, 1972. - $152 \mathrm{c}$.

16. тері ли ьвівської держ вної лісовпорядкув льної експедиції по тр дчівському , “озточчя”, “ворівський”, “ ьвівський ”, герівському військовому лісгоспі, ом рнівському лісництві “ мбірське ”, в дівському і п ївському лісництв х “ ьвівське ”. орм № 2 по розподілу вкритих лісовою рослинністю земель... ст ном н 1 січня 2007 року. 
17. тері ли до проекту орг ніз ції і ведення мисливського господ рств “ нів” ьвівської обл сної р ди тов риств “ин мо” / . . елег н, . . ринюк, . . онд ренко. - ьвів, 1999. - 65 с.

18. ояснюв льн з писк перспективного пл ну орг ніз ції т розвитку держ вного мисливського господ рств " ворівське" ьвівської обл сті / . . рп , . . ромов, . . йт л .- ьвів, 2002. -235 с.

19. роект орг ніз ції т розвитку мисливського господ рств “ерещиця” “ ьвівський облрибкомбін т”/ . . еркез. - ьвів, 2006-2007. - 70 с.

20. т тистичні д ні по веденню мисливського господ рств в угіддях ородоцької р йр ди ьвівської обл сті / . . остяк. - ьвів, 2010. - 32 с.

21. т тистичні д ні продуктивності риби ьвівської дослідної ст нції нституту рибного господ рств кр їни. - еликий юбінь, 2012. - 21 с.

m ття: н дійшл до ред кції 15.03.2014 доопр иьов н 05.05 .2014 прийнят до друку 25.06.2014

\title{
ANALYSIS OF STATE OF BIOTIC RESOURCES OF VERESHCHYTSIA RIVER BASIN
}

\author{
Volodymyr Grekh ${ }^{1}$, Oksana Kormylo ${ }^{2}$, Semen Kukurudza ${ }^{2}$ \\ ${ }^{1}$ Lviv research station of Institute of fishing NAAS of Ukraine \\ Lvivska Str., 11, 81555 - UA Velykyj Lubin, Lviv Region, Ukraine \\ ${ }^{2}$ Ivan Franko National University of Lviv, \\ P. Doroshenko Str., 41, UA - 79000 Lviv, Ukraine
}

The resources of plants (forest and meadow-marsh), animals (hunting and fishing) on example of the drainage basin of river Vereshchytsia as clearly defined the terrestrial-watery spatio-functional geosystem are analysed. Also the role of phyto- and zooplankton in the improving of the forage base fisheries is analysed. The relationships and the interdependences of abiotic and biotic components of the environment and the impact of the anthropogenic factors on them are considered.

Key words: biotic resources, drainage basin, river basin approach, rational use, reproduction, protection of biota. 